\title{
SPIB wt Allele
}

National Cancer Institute

\section{Source}

National Cancer Institute. SPIB wt Allele. NCI Thesaurus. Code C99652.

Human SPIB wild-type allele is located within 19q13.3-q13.4 and is approximately $10 \mathrm{~kb}$ in length. This allele, which encodes transcription factor Spi-B protein, plays a role in the positive regulation of transcription. 